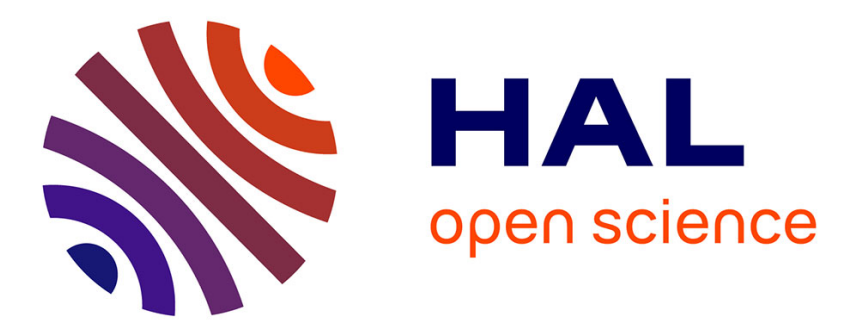

\title{
From women's empowerment to food security: Revisiting global discourses through a cross-country analysis
}

Floriane Clement, Marie-Charlotte Buisson, Stephanie Leder, Soumya Balasubramanya, Panchali Saikia, Ram Bastakoti, Emma Karki, Barbara van Koppen

\section{To cite this version:}

Floriane Clement, Marie-Charlotte Buisson, Stephanie Leder, Soumya Balasubramanya, Panchali Saikia, et al.. From women's empowerment to food security: Revisiting global discourses through a cross-country analysis. Global Food Security, 2019, 23, pp.160-172. 10.1016/j.gfs.2019.05.003 . hal-02401236

\section{HAL Id: hal-02401236 \\ https://hal.science/hal-02401236}

Submitted on 25 Oct 2021

HAL is a multi-disciplinary open access archive for the deposit and dissemination of scientific research documents, whether they are published or not. The documents may come from teaching and research institutions in France or abroad, or from public or private research centers.
L'archive ouverte pluridisciplinaire HAL, est destinée au dépôt et à la diffusion de documents scientifiques de niveau recherche, publiés ou non, émanant des établissements d'enseignement et de recherche français ou étrangers, des laboratoires publics ou privés.

\section{(ㄷ)(1) $\$$}

Distributed under a Creative Commons Attribution - NonCommerciall 4.0 International 


\section{From women's empowerment to food security:}

\section{Revisiting global discourses through a cross-country}

\section{analysis}

Floriane Clement $^{1,2 *}$, Marie-Charlotte Buisson ${ }^{1}$, Stephanie Leder $^{3}$, Soumya

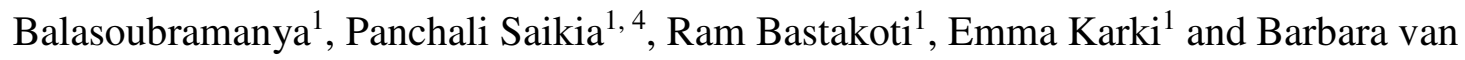

Koppen $^{1}$

${ }^{1}$ International Water Management Institute (IWMI)

${ }^{2}$ DYNAFOR, Université de Toulouse, INPT, INRA, Toulouse, France

${ }^{3}$ Swedish Agricultural University, Uppsala, Sweden

${ }^{4}$ Stockholm International Water Institute (SIWI), Stockholm, Sweden

*corresponding author, mailing address: INRA, UMR Dynafor, 24 Chemin de Borde Rouge, Auzeville CS 52627, 31326 Castanet Tolosan Cedex - France, Tel. : + 33 (0) 5.61.28.52.61, floriane.clement@inra.fr 


\title{
From women's empowerment to food security:
}

\section{Revisiting global discourses through a cross-country}

\author{
analysis
}

\section{Abstract}

Global discourses have advocated women's empowerment as a means to enhance food security. Our objective was to critically review the causal linkages between women's empowerment and food availability and access. We relied on mixed methods and a crosscountry analysis, using household survey data from Bangladesh, Nepal and Tajikistan and qualitative data from Nepal. The quantitative analysis highlights the diversity of patterns linking empowerment and food security indicators and the roles socio-economic determinants play in shaping these patterns across countries. The qualitative analysis further stresses the need for a truly intersectional approach in food security programmes that supports challenging the structural barriers that keep marginalised men and women food insecure. Lastly, our findings call for informing standardised measures of empowerment with an assessment of local meanings and values.

Keywords: food security; women's empowerment; gender; intersectionality; multi-country analysis; mixed-methods study 


\section{Introduction}

2 Global food security debates have framed gender equality as an effective tool to support

3 agricultural and economic growth and enhance food security (ADB, 2013; Duflo, 2012) - a

4 narrative that particularly resonates with increasing patterns of male out-migration and the so-

5 called 'feminisation of agriculture'. Many studies have evidenced strong linkages between

6 gender inequality and food insecurity, notably in the case of poor and marginalised women

7 who have less access than men to critical resources for agricultural livelihoods (Quisumbing

8 and Pandolfelli, 2010) or in respect to how women's disempowerment affects maternal and

9 child nutrition (Malapit et al., 2015a; Malapit and Quisumbing, 2015; Nisbett et al., in press;

10 Sraboni et al., 2014).

11 Food security discourses envision that if women have similar access to productive resources

12 as men, agricultural productivity will increase, thereby contributing to enhanced food

13 security, e.g. 'Increasing women's access to land, livestock, education, financial services,

14 extension, technology and rural employment would boost their productivity and generate

15 gains in terms of agricultural production, food security, economic growth and social welfare"

16 (FAO, 2011).

17 Some would argue that this instrumental narrative represents a strategic and necessary step to

18 attract the attention of international development agencies and policy-makers to gender

19 inequalities in agriculture globally. Indeed it has to some extent contributed to the inclusion of

20 women's empowerment components in food security programmes, deploying interventions

21 that have specifically targeted women. It has also been visible in the monitoring and

22 evaluation of these programmes, and in particular in the development and implementation of

23 the Women's Empowerment in Agriculture Index (WEAI), a tool designed to measure the

24 impact of USAID programmes under the Feed the Future initiative (Alkire et al., 2013). 
Yet the operationalization of this narrative linking women's empowerment through access to productive resources to increased food security has so far largely failed to deliver on its promises, both in terms of actual investments dedicated to women's empowerment, and resulting outcomes on gender equality and enhanced food security (Galie and Kantor, 2016). Some scholars remark that such policy discourse promotes a narrow and apolitical vision of women's empowerment (Galie and Kantor, 2016), which is symptomatic of development programmes in general. The latter have often focused on economic empowerment without necessarily addressing the norms, institutions and broader political economic structures that (re)produce gender inequalities in the first place (Batliwala and Dhanraj, 2004; Cornwall and Edwards, 2010; Kabeer, 2005; O'Laughlin, 2007). Stevano (2017) also points to the structural gendered forms of deprivation that generate food insecurity such as lack of secure employment and conflicting labour demands.

Our study aims at bringing fresh insights on the relationships between women's empowerment and food security through an intersectional perspective and a mixed methods approach across multiple countries. Intersectionality refers to "the ways in which forms of social difference (race, class, gender, disability, among identities) 'add up' to circumscribe how people see themselves and how they are seen in the social milieu, leading to various forms of discrimination or privilege" (Butler, 1997 in Nightingale, 2015). We first explored women's empowerment and food security relationships relying on quantitative data from three household surveys conducted in Bangladesh, Nepal and Tajikistan. We then critically reflect on the findings of our statistical analysis, based on qualitative data collected in two communities in Nepal. The communities were selected from project interventions under the same development project and region as where the household survey was conducted, in order to link the qualitative data analysis to the quantitative data analysis. 
We largely draw on Kabeer's empowerment framework (1999) for our analysis. Kabeer (1999) defines power as one's ability to make choices and distinguishes three inter-related dimensions to the process of empowerment: resources (material and non-material, i.e. human and social), agency and achievements. Agency does not only encompass observable actions but also the motivation for these actions and the meanings given to them. We also include under agency one's ability to influence through positions and identities. For instance, in some societies, the elder man can influence the actions or behaviours of his family members solely by his mere position and identity, without any verbal actions or decisions.

We also reckon that power does not necessarily lie in individuals but is also pervasive in the form of what Bourdieu coined 'doxa' (1977 in Kabeer, 1999) or the latent form of power (Lukes, 2005) that ensures acceptance of domination: what appears normal and natural is not contested or even perceived unfair. This pervasive form of power was particularly evidenced in Foucault's writings on how power is embedded in daily practices, institutions and discourses (e.g. Foucault, 1975). In feminist studies, this is what Rowlands (1998) refers to as ‘internalised oppression’ whereby power is exercised through the mere acceptance of dominant norms, rules, relationships and the development of a belief that these are normal, just and legitimate. This leads us to add the concept of 'critical consciousness', developed by Freire (1970) to the three other dimensions of empowerment, as proposed earlier by other gender and development scholars (Cornwall, 2016; Cornwall and Gaventa, 2001; Goldman and Little, 2015; Leder, 2016). Critical consciousness denotes one's ability to realize and react on the structures and other forms of power that produce inequalities and exclusion. In this perspective, reflective argumentation skills are a pre-condition for transformative change and sustainable development (Leder, 2018). 
To define food security, we rely on the FAO definition: «Food security, at the individual, household, national, regional and global levels [is achieved] when all people, at all times, have physical and economic access to sufficient, safe and nutritious food to meet their dietary needs and food preferences for an active and healthy life » (FAO, 1996). We distinguish between food insecurity as a state and as a process (as Kabeer proposes for poverty, see Kabeer, 2015). Food insecurity as a state is what is observed at a given point in time, whereas food insecurity as a process reflects the mechanisms and structural causes that create food insecurity. We expect that food insecurity as a state affects and is perceived by men and women differently (Coates et al., 2010) while food insecurity as a process is created through distributive and procedural mechanisms that exclude men and women differently. In our quantitative analysis, we particularly examine the linkages between agency and achievements, as it has been, until recently, relatively less studied than the relationship between resources and achievements in the gender and food security literature. Food security is the broad achievement considered here, but we mostly considered food availability and, to some extent, food access, among the four following elements of food security: availability; access; safety, nutrition and sanitation; stability and environment. Following the entitlement approach, we recognise the various mechanisms which people draw upon to acquire food, as well as their ability to draw on multiple mechanisms and diversify risk, understood as 'capabilities' (Sen, 1981). A central assumption in our approach is to posit that these capabilities are shaped not only by gender but also by other social markers and identities, such as age, caste, class, ethnicity, religion etc. These do not simply 'add up' to each other but intersect to form new forms of vulnerability to food insecurity. Empowerment is a key process that allows entitlements to be realised, secured or claimed (Drèze and Sen, 1989). In a food sovereignty perspective, empowerment is also critical for smallholder farmers to gain the 
right to control over food production and define their own food and agriculture policy (Patel, 2012).

\subsection{Quantitative data collection and analysis}

We used the quantitative data collected through a household survey across three different projects conducted in Bangladesh, Nepal and Tajikistan. In the case of Nepal, the survey was designed by the research team for the purpose of the impact evaluation of a development project implemented by an international non-governmental organisation (INGO). The surveys for these three projects did not specifically aim at exploring relationships between food security and women's empowerment but collected data on agricultural practices, water management and on different components of food security and women's empowerment/agency (Table 1). We therefore used a heterogeneous set of variables as indicators of women's empowerment and food security. Our intention was not to compare results across countries but rather to explore different types of relationships between empowerment and food security across a wide range of contexts.

In the case of Bangladesh and Tajikistan, the variables considered for women's empowerment are largely related to agency in the form of decision-making. For Nepal, we used the indicators of a more elaborate index, drawing on the WEAI developed by IFPRI and OPHI (Alkire et al., 2013). The WEAI is an aggregate index based on individual level data on men and women within the same households. The WEAI comprises of two sub-indexes: 1) the five domains of empowerment (5DE); and 2) the gender parity index (GPI). The 5DE sub-index attempts to assess the roles of women in agriculture as well as their level of engagement in this sector to reflect their status of empowerment in five domains of empowerment: (1) 
120 decisions over agricultural production, (2) access to and decision-making power over

121 productive resources, (3) control over use of income, (4) leadership in the community, and (5)

122 time use (Alkire et al., 2013). We used the Abbreviated WEAI (A-WEAI) for the purpose of

123 the project impact evaluation. The A-WEAI was developed as a shorter and streamlined

124 version of the WEAI and includes six indicators under the 5DE: inputs in productive

125 decisions, ownership of assets, access to and decisions on credit, control over use of income,

126 group membership and workload. We used for our analysis, the indicator variables for

127 whether the primary female in the household is empowered (binary) (Malapit et al., 2015b),

128 as we felt that considering different domains of empowerment would allow a more nuanced

129 analysis than if we used the aggregate A-WEAI scores.

130 For food security, we relied on a mix of indicators related to self-consumption strategies,

131 likelihood of facing a food shortage, coping strategies in case of food shortage and

132 malnutrition anthropometric indicators (wasting, stunting and under-weight for children under

133 two years old) (Table 1). These are broadly related to food availability, food access and actual

134 undernutrition.

135 To quantify the correlation between the women's empowerment variables and the food

136 security indicators, we used multivariate regressions to control for household-level attributes

137 that may conjointly affect the food consumption behaviour, food shortages as well as the

138 choice of a coping strategy. Ordinary Least Square regressions are used when the dependant

139 variable is continuous. In the case of binary dependant variables, Logit regressions were

140 preferred and marginal effects reported. Finally, for censored dependant variables, as the

141 number of months, results from Tobit regression are presented. All tables and figures

142 showing the results from the quantitative analysis are provided in the Appendix.

143 In the same time, we explored to which extent our indicators of women's empowerment and

144 food security were associated with household-level socio-economic indicators. We used three 
145 types of socio-economic indicators: wealth, class (land ownership), female-headed household

146 and we added one indicator related to caste and ethnicity for Nepal. Poverty has been found to

147 aggravate gender inequalities, notably in terms of nutrition in Bangladesh (Kabeer, 2015;

148 Sraboni et al., 2014). Land ownership is a strong determinant of both wealth and food security

149 in the South Asian context particularly - it was not included in the analysis for Tajikistan,

150 where land is less a limiting factor for food security. Female headship is also a recurrent

151 indicator of how gender inequalities intersect with poverty across countries (Kabeer, 2015)

152 and with food security (ADB, 2013). In the case of Nepal, Dalit women (Dalits are former

153 untouchables and lowest in the social hierarchy) are particularly vulnerable to poverty and

154 food insecurity (UNDP, 2014), as they face double discrimination and marginalisation

155 (Bennett, 2008). Similarly Janajati, who include diverse indigenous groups in the hills and

156 Terai-Madhesh region of Nepal, have historically suffered from socio-economic and political 157 exclusion and marginalisation.

158 


\begin{tabular}{|c|c|c|c|}
\hline & Bangladesh & Nepal & Tajikistan \\
\hline Name of & Aquatic Agricultural System & Building Resilience and & "Impact of Water Users \\
\hline \multirow[t]{4}{*}{ project } & CGIAR Research programme & Adaptation to Climate & Associations on Water and \\
\hline & "Community water & Extremes and Disasters & Land Productivity, Equity \\
\hline & management from a micro level & (BRACED) - Anukulan & and Food Security in \\
\hline & perspective" & & Tajikistan" \\
\hline Type of & Project baseline household & Project baseline household & Project household survey \\
\hline survey & survey & survey & \\
\hline Districts/ & Khulna Hub (Polder 3, 30, 29, & Bardiya, Dadeldhura, Doti, & Khatlon Region $\neq(116$ \\
\hline \multirow[t]{6}{*}{ Region } & $43 / 2 f)$. The Unions included & Kailali, Kanchanpur and & jamoats selected), Sughd \\
\hline & were Noapara, Tarali, & Surkhet & Region (21 jamoats \\
\hline & Gangarampur, Batiaghata, & & selected) and districts of \\
\hline & Sarappur, Sahas. & & Republic Subordination \\
\hline & & & Region (27 jamoats \\
\hline & & & selected) \\
\hline Survey date & August 2015 & January 2016 & March 2016 \\
\hline Sample size & 672 households & 600 households & 1920 households \\
\hline $\begin{array}{l}\text { Sex of the } \\
\text { respondent }\end{array}$ & $\begin{array}{l}\text { Household head. Majority of } \\
\text { the respondent }(86.8 \%) \text { were } \\
\text { male. }\end{array}$ & $\begin{array}{l}\text { Adult main male and } \\
\text { female decision-makers for } \\
\text { the A-WEAI indicators } \\
\text { Household head for the } \\
\text { data on food security and } \\
\text { household characteristics }\end{array}$ & Adult female \\
\hline Sampling & 30 households randomly & 600 households from 20 & From 164 jamoats \\
\hline methodology & selected and surveyed in each & VDCs (10 treated VDCs & irrigated by gravity \\
\hline for & village across 24 marginalised & and 10 non-treated VDCS). & irrigation schemes, 80 \\
\hline households & villages & & were randomly chosen; 2 \\
\hline & & & villages were randomly \\
\hline
\end{tabular}


selected from each jamoat

(160 villages in total); in

each of the selected

villages, 12 households

were randomly selected

from a list of households.

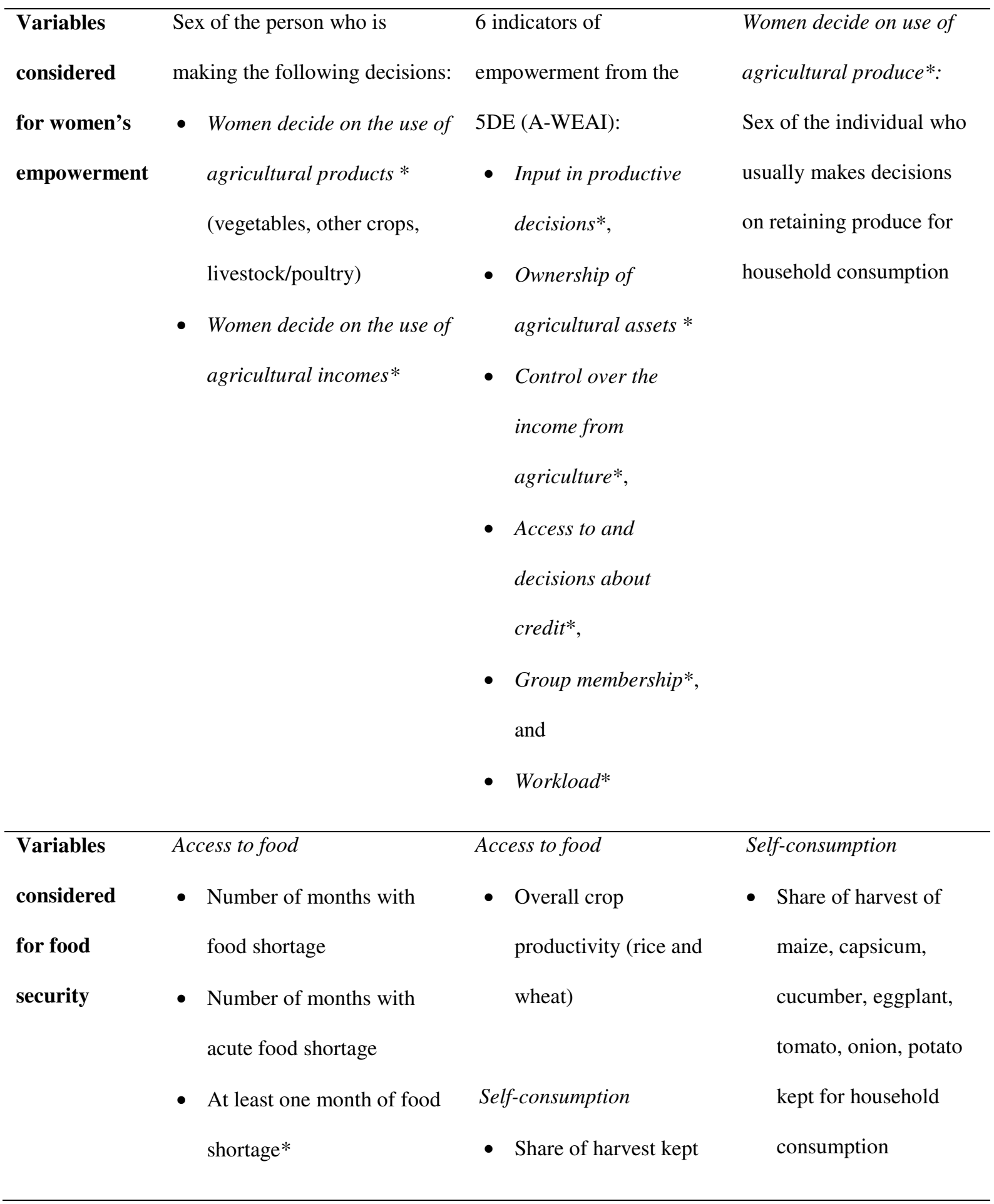


Self-consumption

- Share of aman rice, vegetables, aquaculture/fish kept for self-consumption

\section{Coping strategies}

- Rely on cheap, less expensive and less preferable food*

- Reduce the quantity of intake of food*

- Spend days without eating any food*

- Borrow from relatives/friends for food*

- Purchased food on credit*

- Eat stored seeds*

- Sell household goods for money* for self-consumption

for cereals (rice and wheat) and vegetables

Undernutrition

- Under 2 children suffering from stunting* $($ HAZ $<-2)$

- Under 2 children

suffering from wasting* $(\mathrm{WAZ}<-2)$

- Under 2 children

suffering from underweight* (WHZ<-

2)

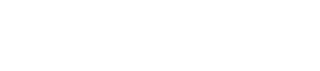

Coping strategies

Household adopts/does not

adopt the following

strategy:

- Rely on cheap, less expensive and less preferable food*

- Reduce the quantity of intake of food in each meal *

- Reduce the number of times food is eaten per day*

- Spend days without eating any food*

- Borrow from relatives/friends for food*

- Purchased food on credit*

- Ate crop seed that was stored for cultivation*

- Sold household items to purchase food*

\begin{tabular}{|c|c|c|c|c|}
\hline Socio- & - Household wealth index $* *$ & $\bullet$ & Area of owned & - Dummies for source of \\
\hline economic & - Area of owned land & & land & domestic water: \\
\hline household- & - Female-headed household* & $\bullet$ & Female-headed & Presence of piped \\
\hline level variables & (the main decision-maker & & household*(the & water in the house*, or \\
\hline considered & of the household is female) & & main decision- & household fetches \\
\hline
\end{tabular}




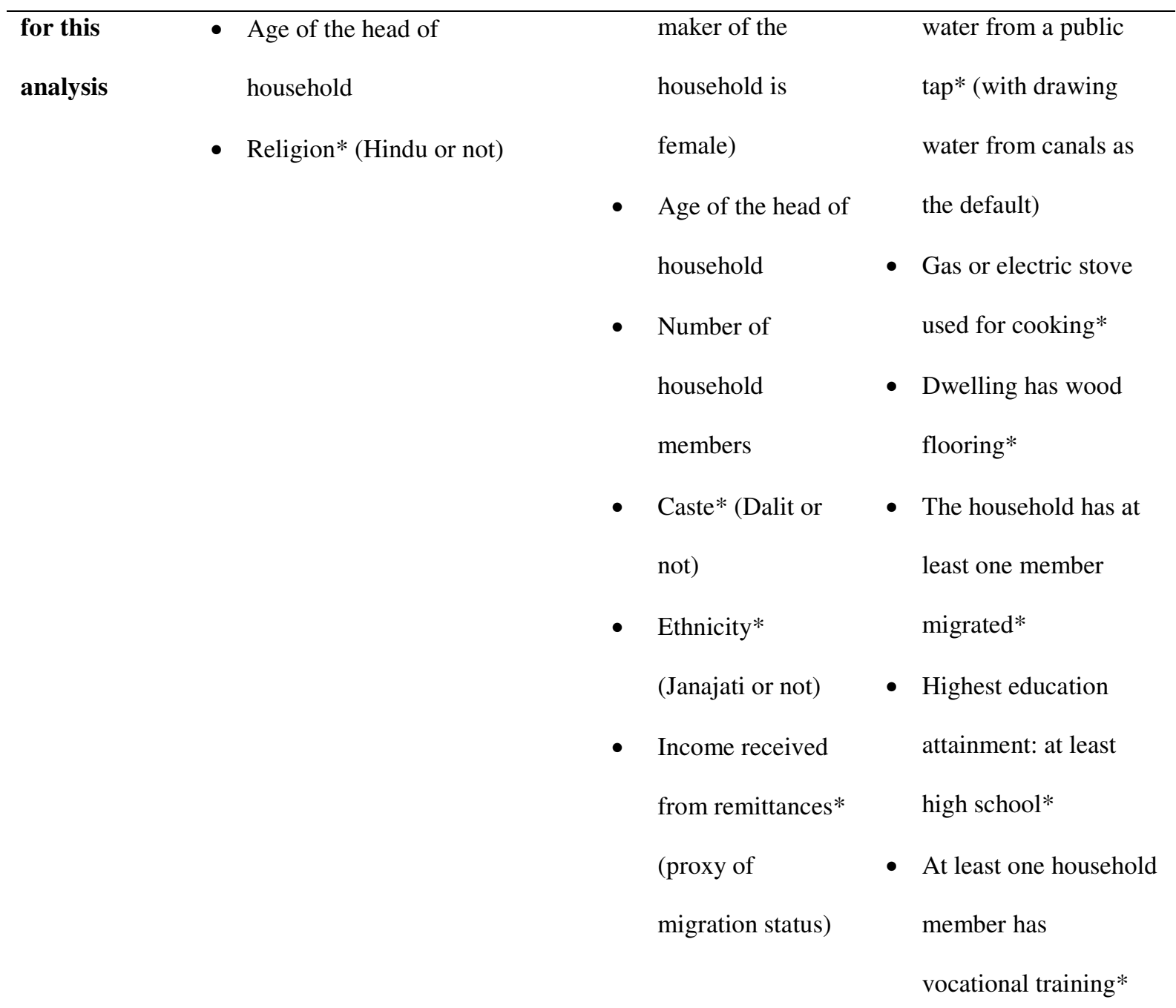

$160 \neq$ Tajikistan is divided into four regions, and the capital city of Dushanbe. The regions are Sughd, Districts of

161 Republican Subordination, Khatlon, and Gorno-Badakhshan Autonomous. Each region is divided into districts,

162 and each district into jamoats, which are the lowest administrative units.

$163 *$ Binary variables

$164 * *$ The household wealth index was built using a principal component analysis with indicators of asset

165 ownership, type of house and electricity access.

166 The characteristics of the households sampled are presented in Table 2. 


\begin{tabular}{|c|c|c|c|}
\hline Population characteristics & Bangladesh & Nepal & Tajikistan \\
\hline Average household size & 5.2 & 5.7 & 4.8 \\
\hline Proportion of female-headed households (\%) & 13 & 35 & 14 \\
\hline Average age of household head & 46 & 42 & 53 \\
\hline \multicolumn{4}{|l|}{ Religion, caste and ethnicity (\% distribution) } \\
\hline Dalit and marginalised groups & & 16.6 & - \\
\hline Janajati & & 40.9 & \\
\hline Hindu & 61.5 & - & - \\
\hline Muslim & 37.9 & - & - \\
\hline \multicolumn{4}{|l|}{ Vegetable cultivation } \\
\hline Proportion of households cultivating vegetable & 55 & - & 75 \\
\hline on homestead land (\%) & & & \\
\hline \multicolumn{4}{|l|}{ Agricultural land holding } \\
\hline Households owning agricultural land (\%) & 100 & 97 & 99 \\
\hline Average size of agricultural land (ha) & 0.51 & 0.37 & 12.65 \\
\hline Percentage of holdings operating less than 0.5 ha & 64.7 & 74.0 & 0.0 \\
\hline
\end{tabular}

170 In Bangladesh, households rely on both farming and aquaculture. Rice is the staple crop

171 whereas households also grow vegetables in the homestead garden. In Nepal, households

172 cultivate rice or rice and wheat depending on the location, whereas women often cultivate

173 vegetables in home gardens, primarily for home consumption. The surplus sold on the market

174 provides them a small income, which is usually used for school fees or petty household

175 expenses (Clement and Karki, 2018). As visible in the proportion of female-headed

176 households, migration is an important risk diversification strategy in Nepal, with the hope to

177 reduce food insecurity through sending remittance that enable other members of the

178 household to obtain food. In Tajikistan, home gardens are an important production system for 
179 the household. Earlier, they were used to cultivate vegetables and fruits to augment the

180 family's diet but recently they have also emerged as a source of cash income through sale of

181 surplus.

182

183

184

185

186

187

188

189

190

191

192

193

194

195

196

197

198

199

\subsection{Qualitative data collection and analysis}

The qualitative component of our study considers food insecurity as a process, exploring some of the structural causes that create food insecurity.

In Nepal, the qualitative study was conducted between November 2015 and May 2016 as part of the BRACED project under which also the quantitative data were collected. We selected two communities in Dadeldhura and Doti districts, based on the diversity of caste and ethnic groups among the beneficiaries and different types of interventions conducted.

The INGO envisioned in this project multiple pathways linking women's empowerment and increased food security: women's enhanced access to water for both domestic and productive uses and women's membership in vegetable farming groups would allow them engaging in irrigated homestead vegetable gardening. Vegetable production would in turn contribute to a more diverse diet and enhanced maternal and child nutrition, while the sale of vegetable products would increase household income and thus its resilience to external climatic shocks.

The objective of our study was to capture local meanings of empowerment and understand the causal processes and mechanisms that link women's empowerment in agriculture to household food security and resilience to shocks.

The research team started with a transect walk, village resource mapping and a participatory power ranking to understand social hierarchies and differentiated access to natural resources in the community. Then, 5-6 key informant interviews were conducted in each community and several focus group discussions (FGDs) disaggregated by sex and household power category on empowerment. Eight women were selected based on their household power category covering high, middle and low power categories, to conduct and discuss power-self 
rankings and jointly reflect on their own A-WEAI score. Lastly in-depth interviews were conducted with 12-15 women in each community to explore life histories, household livelihood strategies, project implementation outcomes, access to drinking water and irrigation facilities, group membership and access to credit, and involvement in household and community-level decision-making.

\section{Results}

\subsection{Relationships between indicators of women's empowerment and food security}

\subsubsection{Self-consumption}

In Bangladesh, results indicate that women's decision on how the agricultural production should be used (sold, self-consumed or stored) significantly determine the share of the vegetable harvest retained for self-consumption. However, their decision is not a determinant of the share of aman rice and fish kept for self-consumption (Table B1). This is in line with earlier research findings on women's role to ensure household food security in Bangladesh (Sraboni et al. 2014) and traditional gendered division of family labour, with women having more labour input and control over homestead vegetable gardening and men more control over rice production, fishing and marketing of these products (Rahman, 2000; Sultana and Thompson, 2008).

In Nepal, results are mixed: when women are empowered in terms of access to and decisions about credit, a significantly larger share of both vegetable and cereal production is kept for home consumption (with cereal production and marketing usually under the male domain). The relationship is the opposite for vegetable production when women were empowered in terms of control over the income (Table N1). This could be explained by the fact that homestead vegetable production and sales are often a significant - or the only - component of 
rural women's income in the sampled region - so the direction of the relationship might

228 therefore be opposite than the one expected: when women sell a larger share of vegetables,

229 they have more control over income.

230 In Tajikistan, women's decision-making only had a significant effect on the amount retained

231 in the case of maize, which is used both for animal and human consumption: when women

232 decide on the use of maize product, slightly less of the harvest is retained for home

233 consumption (Table T1).

\subsubsection{Access to food}

In Bangladesh, decisions by women on the use of the agricultural produce and the use of the incomes from crop sales are significantly associated with a reduction of the number of months

237 faced with food shortage, with acute food shortage and even the likelihood to face a food 238 shortage (Table B2). Interestingly, the coefficients are higher for the decision on the incomes 239 than for the decision on the produce.

240 In Nepal, we use information on crop productivity as a proxy of food availability. The 241 relationship between women's decisions over income and wheat productivity is positive 242 (Table N2). However the access to and decision about credit is negatively associated with 243 wheat productivity. The relationship between women's empowerment and food availability 244 and its direction is therefore unclear - but in line with earlier results on self-consumption.

245 Women's empowerment over credit is both significantly correlated with lower wheat 246 productivity and a greater share of cereals kept for self-consumption.

\section{4.1.3. Coping strategies}

248 In Bangladesh, when women primarily take decisions on the use of agricultural produce, the 249 likelihood to rely on cheap food is reduced by $8 \%$, all things being equal and compared with 250 other households. Similarly, the likelihood to eat stored seeds is reduced by $2 \%$ with women 251 deciding the allocation of agricultural produce. The decision of women on the incomes from 
agriculture also reduce the probability of using a coping strategy, namely the use of cheap

253 food (minus 19\%), the reduction of food quantity (minus 11\%) and the use of credit for

254 purchasing food (minus 10\%) (Table B3), results which are in line with the relationship with

255 reduced food shortage.

256 Results are opposite in Tajikistan. In households where women are primarily responsible to

257 determine the use of vegetables through the year, those households are likelier than others to

258 rely on food shortage coping strategies that smoothen out the fall in consumption, such as

259 relying on cheaper food (16\% more likely), reducing the quantity of food intake in each meal

260 during food shortfalls (12\% more likely), or purchasing food on credit ( $8 \%$ more likely)

261 (Table T2).

262 4.1.4. Undernutrition

263 In the case of Nepal, anthropometric measures have been collected for children under two

264 years old. The access to and decisions about credit for women significantly reduce the

265 likelihood for the children of the household to face stunting and underweight (Table N3).

266 To sum-up, our results suggest mixed and unexpected findings on the relationship between

267 women's agency and food availability and access. The relationship varies in terms of type of

268 agricultural product considered, type of decisions taken, type of indicator of empowerment,

269 and across the three countries. To further our analysis, we explored how the relationships

270 between women's empowerment and food security depend on socio-economic indicators

271 across the three study countries. We therefore unpack 'women' as a category to explore how

272 different types of social markers and identities affect how agency translates into

273 achievements. 
In Bangladesh, wealth is negatively and significantly associated with food shortage and use of

277 almost all coping strategies. As expected, wealthier households are less likely to be food 278 insecure and to rely on food coping strategies (Tables B2 and B3). Wealth is not significantly 279 associated with the share of agricultural products kept for home consumption, whereas in 280 Nepal, households from higher class (reflected in terms of area of owned land) keep a lower 281 share of cereals for self-consumption (Table N1), which is in line with expectations.

282 However, in Tajikistan, female decision-makers from wealthier households ${ }^{1}$ are $16 \%$ more 283 likely to purchase food on credit and $20 \%$ more likely to borrow money from friends than 284 other decision-makers (Table T2). The set of coping strategies adopted by wealthy female 285 decision-makers thus partly differs from that of other decision-makers as a whole, who are 286 more likely to eat cheap food, reduce food quantity and purchase food on credit. This suggests 287 that wealth influences the set of coping strategies available to or/and adopted by women.

\subsubsection{Female-headed households}

In Bangladesh, female-headed households are found to be more likely to face food shortage (Table B2), which could be explained that, in the context of Bangladesh, these households are 291 poorer (Kabeer, 2015) and, we suspect, might have more limited social networks, less access 292 to information and might face greater exclusion from the provision of public services. We also found a significant and positive effect of female-headed households on the likelihood to rely on cheap food (Table B3). In Nepal, women from female-headed households reported N1), but we did not observe any effect on crop yields and child nutrition (Tables N2 and N3).

297 In Tajikistan, females who make decisions in households with male migrants ${ }^{2}$ are $14 \%$ less likely to switch to cheap food and $9 \%$ less likely to reduce quantity of food consumed (Table

\footnotetext{
${ }^{1}$ The product of a dummy variable that takes a value of 1 when the sex of the decision maker is female and a dummy variable that denotes that presence/absence of piped water in the household

${ }^{2}$ Product of a dummy variable that takes a value of 1 when the sex of the decision maker is female and a dummy variable that denotes the presence/absence of male migrants in the household
} 
T2, which in this case suggests that women use remittances to reduce food insecurity in the

300 household.

\subsubsection{Caste and ethnicity}

302 In Nepal, the effect of Dalit caste is not significant on any of our food security indicators,

303 which is at first glance surprising as Dalits are still among the poorest in Nepal (UNDP,

304 2014). This might be because a high proportion of Dalits is still landless (NSIS, 2012), hence

305 we cannot find any direct linear relationship between caste and agricultural productivity

306 indicators. Janajati households retain a larger share of vegetable for their own consumption

307 (Table N1) and they also achieve higher productivity of rice and wheat, all things being equal.

308 (Table N2). This is also unexpected, but might due to the high proportion in our sample of

309 Janajatis living in Terai Madesh, a region characterised by higher landholdings and crop

310 productivity than the hill districts surveyed.

312 We now turn to our qualitative data from two communities in Western Nepal to delve into the

313 complexity that characterises the relationships between women's agency and food availability

314 and access. Our findings evidence new variables and processes that were not captured by the

315 quantitative analysis, notably related to empowerment. We first examine agency at the intra-

316 household level, in the particular situation of women with migrated husbands. Then, we

317 broaden our analysis to consider how social relationships beyond the household shape access

318 to productive resources and agency.

319 4.3.1. Intra-household agency

320 Nepal has seen an increase in long-term male out-migration to India, Malaysia and Gulf 321 countries, which has affected the distribution of gender roles, responsibilities and resources

322 (Leder et al., 2017; Sugden et al., 2014). In this context, we found that high levels of women's 323 agency, as assessed with the A-WEAI, do not necessarily translate into a feeling of 
empowerment ('shashaktikaran' in Nepali) and in increased food security. In contrast, several women with permanently out-migrated husbands, who were rated "empowered" according to their A-WEAI scores, were rated by other women and self-rated themselves as the least empowered and marginalised in their community.

For example, for one of our respondents, Kamala, the A-WEAI indicators indicated that she is empowered in decision-making, based on her position as household head without the presence of in-laws or her husband. However, she stated to feel lonely and worried about her ability to provide quality education and adequate medical care for her son and pay back multiple loans. As phone calls to her husband abroad are expensive, communication and mental support from him are very limited, and her maternal family lives far away. In fact, in FGDs, women identified kins' mental, financial and labor support as a contributing factor to their feeling of empowerment. Conversely, they perceived support to others as a key achievement of empowered women including the ability to help other women in cultivating crops and vegetables: "They [empowered women] can tell us what to grow and how much to plant".

Another woman, Sunita, resides with her three young children while her husband works in Malaysia. She makes minor household decisions, decides on agricultural production and is an active member of savings groups. However, when asked to describe her life, Sunita described her life full of 'dukkha' ('sadness' in Nepali). Her husband's passport was taken away, making him unsure of how to return home and he has only managed to send her NPR 20,000 (USD 200) in the last three years, a small amount considering he took a loan of NPR 160,000 (USD 1,600) to get to Malaysia. When harvest fails due to drought, she works as daily wage labourer, carrying construction material for 200 NPR (1.7 USD) a day, as a coping strategy to be able to purchase food. 
These two particular life stories illustrate how increased control over decision-making within

348 the household does not necessarily match with women's own perceptions of their

349 empowerment. We encountered many women who did not feel empowered by taking

350 decisions while their husband is away. Rather they felt powerless in the face of challenges

351 related to exploitative credit system, social norms, masculine bureaucracies, or double

352 standards to access public services. Yet they did not necessarily see empowerment as

353 challenging the oppressive structures and relationships that shape their lives, but rather

354 prioritized household food security and family harmony. As a daughter-in-law indicated when

355 she shared her life history: "They [in-laws] will tell me what to grow, where to grow. I don't

356 feel like saying anything. They tell me what to do. I don't feel bad about it. That is fine. They

357 know better." (T_I7). This is in line with Bourdieu's notion of 'doxa' - gender and age

358 inequalities within the household are culturally desired and not questioned. In contrast,

359 several other daughter-in-laws mentioned they advise their in-laws, while at the same time

360 being critically conscious of the necessity to respect their elders. This intermediate form of

361 awareness and agency may open up spaces to bring about social change.

362 4.3.2. Looking beyond the household: caste and class

363 In Nepal, Dalits usually reside at the fringe or outside the main settlement, with limited access

364 to land, social networks and information. They lack access to water resources due to religious

365 norms and structural constraints (Nightingale, 2011). In mixed caste communities, existing

366 inequalities in water access have often been reproduced through external water and food

367 security project interventions as local power relationships largely shape their implementation

368 (Clement et al., 2014; Leder et al., 2017).

369 In one of the researched communities in Nepal, the project staff invited all women and men

370 from the communities to participate in meetings to decide on the location of taps before a

371 multiple-use water system (MUS) was built. However, the Dalits, who represent $15 \%$ of the 
population, perceive that the distribution has not been fair as only one of the 22 water taps

373 was installed in their settlement. One contributing factor was the limited ability of Dalit

374 women to influence decisions due to the dominance of higher caste men during the meetings.

375 In addition, their landlessness or almost landlessness was stated as an important hindering

376 factor to receive a tap, as the BRACED project targeted households who could use the water

377 to grow vegetables in their home garden. Dalits were not only excluded but also negatively

378 affected by the project intervention. While higher caste households benefited from greater

379 access to water taps, women of these households would less frequently go to the old

380 communal water taps and natural water sources. Because Dalit women have to rely on other

381 women to fill their vessel, as touching water is culturally not allowed for them, they now have

382 to wait longer times to get water.

383 The way caste, class and inter-household relations intersect to shape food security became

384 very apparent in the case of one landless Dalit research participant, Maya. Maya lives with

385 her two daughters, and her out-migrated husband in Malaysia has neither sent remittances nor

386 news. Maya is the one who makes decisions at home, however, as an agricultural wage

387 laborer, she is dependent on landowners for her household food security, and in particular on

388 an elderly high caste Chhetri "mother", who took her under her care and allows her to stay

389 next to her house in exchange of free agricultural and domestic labor. Thanks to her close

390 relation to this Chhettri woman, she developed both as an outspoken leader among the Dalits,

391 but also as a critically scrutinized woman in the village. Her privileged geographical location

392 also makes her less prone to food shortages than other Dalits, who live closer to the mountain

393 stream and are more exposed to monsoonal floods and landslides. . Her multiple gendered and

394 caste subjectivities demonstrates how leadership is complicated and shifting over social

395 spaces: as a Dalit, she belongs to the most marginalized group within the community,

396 considered impure in the Hindu caste system. Nevertheless, she is much more privileged than 
other Dalits due to her social relation to a Chhetri and a privileged geographical location as

398 she is less prone to food shortages than other Dalits, who live closer to the mountain stream and are more exposed to monsoonal floods and landslides.

\section{Discussion and conclusion}

401 Reflecting on our findings in light of our framework constituted by resources, agency, achievements and critical consciousness, a few interesting lessons for food security debates and programmes emerge.

404 First, when examining the linkages between women's agency and food security achievements

405 with a quantitative analysis, we evidenced that different indicators of agency and even

406 different types of decisions within one indicator of agency are associated with different

407 components of food security. These results are in line with earlier studies (e.g. Malapit et al., 408 2015a; Malapit and Quisumbing, 2015) but our cross-country analysis further highlights the 409 diversity of patterns and the diversity of roles that socio-economic structures play in shaping 410 these patterns across countries.

411 This points to the challenges to select the right indicators and to conduct cross-country 412 comparative analyses with similar sets of indicators. Our quantitative analysis shows 413 interesting patterns between women's empowerment and food security but their diversity 414 across countries and across indicators of empowerment and food security raises more 415 questions than provides answers. Whereas the quantitative findings point to some of the intra416 community and intra-household factors that influence the pathways linking women's 417 empowerment and food security, the qualitative analysis from Nepal allows digging into some 418 of this complexity and evidences how some of these factors, such as caste, class and migration status, among others, intersect to produce different empowerment and food security 
trajectories. This leads us to question the relevance of implementing a one-size-fits-all intervention for empowering rural women farmers or increasing household food security even within one community. We rather defend the importance of adopting a contextualised and intersectional approach in food security programmes that addresses the structural barriers that keep the marginalised, excluded and powerless food insecure. This means disaggregating the category of 'women' for project design, monitoring and evaluation, and moving beyond single distinct categories (e.g. separately considering gender, class, ethnicity), by intersecting categories (e.g. landless Dalit woman, Chhetri woman with migrated husband in small landholding household etc). Beyond caste, ethnicity and class, age and position in the household also matter in feelings of empowerment - this was only slightly touched upon in this paper, but better developed elsewhere, drawing on data from the same sites (Anonymous, 431 forthcoming).

432 Such an intersectional approach then would allow a better understanding of food insecurity as a process: namely, how one's ability to exercise agency to become food secure is embedded 434 in institutions (including social norms) and political-economic structures. In our findings for 435 Bangladesh, increased women's agency reduces the likelihood of their household to face food 436 shortages but female-headed households remain more vulnerable to food shortage even after 437 controlling for women's agency. Similarly, our interviews in Nepal show that the entrenched 438 social barriers for Dalit women to access land and water resources affect their ability to 439 benefit from water and food security projects. Global food security discourses therefore need 440 to bring the role of institutions and political-economic structures to the fore: how they shape 441 the diverse women's and men's differentiated capabilities to benefit from food security 442 programmes, engage in markets, influence food production and distribution systems and food 443 policies. Increased individual agency in agricultural production does not necessarily allow 444 marginalised women overcoming the structural barriers that prevent them achieving what they 
value, including a decent and non-exploitative way to be food secure. Furthermore, in Nepal,

446 social relationships play a central role in perceptions of empowerment through emotional,

447 mental and labor support and the sharing of knowledge and skills across gender, class and

448 ethnicity differences - in this perspective, empowerment largely goes beyond increasing the

449 agency of isolated individuals.

450 Lastly, our qualitative findings underline the importance of jointly examining one's increased

451 agency with the local meanings and values associated to this agency. Increased agency feels

452 like empowerment only when it helps achieving what one values. This has major implications

453 for food security programmes in the context of migration: as women with migrated husbands

454 might be considered more empowered on the basis of decision-making indicators,

455 programmes might shift investments to different targets. Yet in Nepal, these women do not

456 necessarily perceive their increased agency as a form of empowerment. Most of the women

457 we met rather find it stressful, particularly when they lack the mental and emotional support

458 from their relatives to exercise this agency. In addition, our findings point to the role of

459 critical consciousness in the empowerment process: entering male spaces might not be

460 perceived as empowering if the boundaries and norms of these spaces seem 'natural' and

461 remain unquestioned. Food security programmes also have a role to play here - in engaging

462 both marginalised men and women in critical discussions on unequal food production and

463 distribution systems.

\section{Funding sources}

465 This work received financial support from the CGIAR Research Programmes on Aquatic

466 Agricultural Systems and on Water, Land and Ecosystems, from the BRACED programme

467 supported by UKAID from the Department for International Development (grant KPMG 
468 ref. B11 and sub-contract iDE ref. NP 1147), and from the United States Agency for

469 International Development (grant number AID-BFS-G-11-0000). We are grateful to the two 470 anonymous reviewers who provided very constructive comments. 


\section{References}

ADB (Asian Development Bank), 2013. Gender Equality and Food Security- Women's empowerment as a tool against hunger. ADB, Mandaluyong City, Philippines.

Alkire, S., Meinzen-Dick, R., Peterman, A., Quisumbing, A.R., Seymour, G., Vaz, A., 2013.

The Women's Empowerment in Agriculture Index. World Development 52, 71-91.

Anonymous. forthcoming. Intersectional Perspectives on the Gender-Agriculture Nexus:

Relational life histories and additative sex-disaggregated indices. In: Sachs, C., Tickamyer, A.: Changing Gender Relations in Agrarian Transformation. Routledge.

Batliwala, S., Dhanraj, D., 2004. Gender Myths that Instrumentalise Women: A view from the Indian frontline. IDS Bulletin 35, 11-18.

Bennett, L., 2008. Policy reform and culture change: Contesting gender, caste, and ethnic exclusion in Nepal, in: Dani, A.A., de Haan, A. (Eds.), Inclusive States: Social policy and structural inequalities. The World Bank, Washington DC.

Bourdieu, P., 1977. Outline of a Theory of Practice. Cambridge University Press, Cambridge.

Butler, J., 1997. The psychic life of power. Stanford University Press, Stanford, CA.

Clement, F., Basnet, G., Sugden, F., Bharati, L., 2014. Social and environmental justice in foreign aid: A case study of irrigation interventions in western Nepal. New Angle. Nepal Journal of Social Science and Public Policy 3, 65-83.

Clement, F., Karki, E., 2018. When Water Security Programmes Seek to Empower Women: Case study from Western Nepal, in: Fröhlich, C., Gioli, G., Greco, F., Cremades, R. (Eds.), Water Security Across the Gender Divide. Springer, Cham, pp. 151-169. 
493

494

495

496

497

498

499

500

501

502

503

504

505

506

507

508

509

510

511

512

513

514

515

Coates, J.C., Webb, P., Houser, R.F., Lorge Rogers, B., Wilde, P., 2010. “He said, she said”: who should speak for households about experiences of food insecurity in Bangladesh? Food Security 2, 81-95.

Cornwall, A., 2016. Women's Empowerment: What works? Journal of International

Development 28, 342-359.

Cornwall, A., Edström, J., 2014. Challenging Patriarchy: Unsettling Men and Masculinities. Institute of Development Studies, Brighton.

Cornwall, A., Edwards, J., 2010. Introduction: Negotiating empowerment. IDS Bulletin 41, 19.

Cornwall, A., Gaventa, J., 2001. Power and Knowledge, in: Reason, P., Bradbury, H. (Eds.), Handbook of Action Research: Participative Enquiry and Practice. SAGE, London, pp. 70-80.

Drèze, J., Sen, A., 1989. Hunger and Public Action. Clarendon Press, Oxford.

Duflo, E., 2012. Women Empowerment and Economic Development. Journal of Economic Literature 50, 1051-1079.

FAO, 1996. Rome Declaration on Food Security, World Food Summit, 13-17 November 1996. FAO: Rome.

FAO, 2011. The State of Food and Agriculture 2010-2011. Women in Agriculture. Closing the gender gap for development. FAO, Rome.

Foucault, M., 1975. Surveiller et Punir. Naissance de la prison. Gallimard, Paris.

Freire, P., 1970. Pedagogy of the Opressed. Herder and Hered, New York.

Galie, A., Kantor, P., 2016. From Gender Analysis to Transforming Gender Norms. Using empowerment pathways to enhance gender equity and food security in Tanzania, in: Njuki, J., Parkins, J.R., Kaler, A., Ahmed, S. (Eds.), Transforming gender and food security in the 
516 Global South. Routledge and International Development Research Centre, Oxon, UK, New

517 York and Ottawa, pp. 189-215.

518 Goldman, M.J., Little, J.S., 2015. Innovative Grassroots NGOS and the Complex Processes of

519 Women's Empowerment: An Empirical Investigation from Northern Tanzania. World

520 Development 66, 762-777.

521 Kabeer, N., 1999. Resources, Agency, Achievements: Reflections on the measurement of

522 women's empowerment. Development and Change 30, 435-464.

523 Kabeer, N., 2005. Gender equality and women's empowerment. A critical analysis of the third

524 Millenium Development Goal. Gender \& Development 13, 13-24.

525 Kabeer, N., 2015. Gender, poverty, and inequality: a brief history of feminist contributions in 526 the field of international development. Gender \& Development 23, 189-205.

527 Leder, S., 2016. Linking Women's Empowerment and their Resilience. Technical report for 528 BRACED-Anukulan. CGIAR Research Program on Water, Land and Ecosystems (WLE). $52927 \mathrm{p}$.

530 Leder, S., 2018. Transformative Pedagogic Practice. Education for Sustainable Development 531 in Indian Geography Education on Water Conflicts. Springer, Singapore.

532 https://www.springer.com/us/book/9789811323683

533 Leder, S., Clement, F., Karki, E., 2017. Reframing women's empowerment in water security 534 programmes in Western Nepal. Gender \& Development 25, 235-251.

535 Lukes, S., 2005. Power: A radical view, Second Edition ed. Palgrave Macmillan.

536 Malapit, H.J., Kadiyala, S., Quisumbing, A.R., Cunningham, K., Tyagi, P., 2015a. Women's 537 Empowerment Mitigates the Negative Effects of Low Production Diversity on Maternal and 538 Child Nutrition in Nepal. The Journal of Development Studies 51, 1097-1123. 
Malapit, H.J., Kovarik, C., Sproule, K., Meinzen-Dick, R., Quisumbing, A., 2015 b.

540 Instructional Guide on the Abbreviated Women's Empowerment in Agriculture Index (A541 WEAI).

542 Malapit, H.J., Quisumbing, A.R., 2015. What dimensions of women's empowerment in 543 agriculture matter for nutrition in Ghana? Food Policy 52, 54-63.

544 Nightingale, A., 2011. Bounding difference: Intersectionality and the material production of 545 gender, caste, class and environment in Nepal. Geoforum 42, 153-162.

546 Nightingale, A., 2015. Socionature Approach to adaptation. Political transition, 547 intersectionality, and climate change programmes in Nepal, in: Håkon Inderberg, T., Eriksen, 548 S., O'Brien, K., Sygna, L. (Eds.), Climate Change Adaptation and Development.

549 Transforming Paradigms and Practices. Routledge, pp. 219-234.

550 Nisbett, N., Davis, P., Yosefc, S., Akhtard, N., in press. Bangladesh's story of change in 551 nutrition: Strong improvements in basic and underlying determinants with an unfinished 552 agenda for direct community level support. Global Food Security.

553 Nepal Social Inclusion Survey (NSIS), 2012. Central Department of Sociology/Anthropology, 554 Tribhuvan University, Nepal;

555 O'Laughlin, B., 2007. A Bigger Piece of a Very Small Pie: Intrahousehold Resource 556 Allocation and Poverty Reduction in Africa. Development \& Change 38, 21-44.

557 Patel, R.C., 2012. Food sovereignty: Power, gender, and the right to food. PLOS Med 9, $558 \mathrm{e} 1001223$.

559 Quisumbing, A.R., Pandolfelli, L., 2010. Promising approaches to address the needs of poor 560 female farmers: Resources, constraints, and interventions. World Development 38, 581-592. 
561 Rahman, S. 2000. Women's employment in Bangladesh agriculture: composition,

562 determinants and scope. Journal of Rural Studies 16, 497-507.

563 Rowlands, J., 1998. A Word of the Times, but What Does it Mean? Empowerment in the

564 Discourse and Practice of Development, in: Afshar, H. (Ed.), Women and Development:

565 Illustrations from the Third World. Macmillan, London, pp. 11-34.

566 Sen, A., 1981. Poverty and Famine: An essay on entitlement and deprivation. Clarendon

567 Press, Oxford.

568 Sraboni, E., Malapit, H.J., Quisumbing, A.R., Ahmed, A.U., 2014. Women's Empowerment

569 in Agriculture: What Role for Food Security in Bangladesh? World Development 61, 11-52.

570 Stevano, S., 2017. The Limits of Instrumentalism: Informal Work and Gendered Cycles of

571 Food Insecurity in Mozambique. The Journal of Development Studies, 1-16.

572 Sugden, F., Maskey, N., Clement, F., Ramesh, V., Philip, A., Rai, A., 2014. Agrarian stress

573 and climate change in the Eastern Gangetic Plains: Gendered vulnerability in a stratified

574 social formation. Global Environmental Change 29, 258-269.

575 Sultana, P., Thompson, P. 2008. Gender and Local Floodplain Management Institutions A

576 case study from Bangladesh. Journal of International Development 20, 53-68

577 UNDP, 2014. Human Development Report Nepal 2014. 


\section{APPENDIX.}

Table B1. Women's decision and the share of produce retained for feeding the household in Bangladesh

\begin{tabular}{lccc}
\hline & \multicolumn{3}{c}{ OLS regressions } \\
\hline Female decides how to use agricultural produce & Aman rice & Vegetables & Aquaculture \\
Wealth index & -1.506 & $6.111^{* *}$ & 5.338 \\
& $(3.693)$ & $(3.104)$ & $(3.383)$ \\
Area of land owned, in hectare & 0.964 & 0.137 & -0.631 \\
& $(0.878)$ & $(0.720)$ & $(0.792)$ \\
Hindu & 0.418 & $-7.804 * * *$ & 1.296 \\
& $(2.154)$ & $(1.881)$ & $(2.140)$ \\
Female headed household & 2.373 & $7.713 * * *$ & 2.090 \\
& $(3.380)$ & $(2.729)$ & $(2.986)$ \\
Age of the head of the household & -1.363 & $10.26 * *$ & 2.609 \\
& $(4.582)$ & $(4.230)$ & $(4.313)$ \\
N & $0.370 * * *$ & 0.102 & 0.0353 \\
R-squared & $(0.123)$ & $(0.0946)$ & $(0.105)$ \\
\hline
\end{tabular}

Source: Data collected by authors.

All regressions are conducted by authors. The coefficients are reported, along with the standard errors in parentheses.

The standard errors are clustered at the village level. ***, ** and * depict significance at $99 \%, 95 \%$ and $90 \%$ respectively. 
Table N1. Women's empowerment and the share of produce retained for feeding the household in Nepal-OLS regressions

\begin{tabular}{|c|c|c|}
\hline & Cereals & Vegetables \\
\hline \multirow[t]{2}{*}{ Input in productive decisions } & -2.342 & -2.005 \\
\hline & $(2.337)$ & $(2.138)$ \\
\hline \multirow[t]{2}{*}{ Control over the income } & -3.368 & $-3.995 * *$ \\
\hline & $(2.143)$ & $(1.977)$ \\
\hline \multirow[t]{2}{*}{ Ownership of assets } & 0.421 & 1.077 \\
\hline & $(5.549)$ & $(5.390)$ \\
\hline \multirow[t]{2}{*}{ Access to and decisions about credit } & $3.446^{*}$ & $3.186^{*}$ \\
\hline & $(1.806)$ & $(1.654)$ \\
\hline \multirow[t]{2}{*}{ Group membership } & -1.278 & 0.588 \\
\hline & $(1.727)$ & $(1.607)$ \\
\hline \multirow[t]{2}{*}{ Workload } & -0.986 & -0.880 \\
\hline & $(1.971)$ & $(1.848)$ \\
\hline \multirow[t]{2}{*}{ Age head of the household } & 0.0970 & -0.0144 \\
\hline & $(0.0736)$ & $(0.0680)$ \\
\hline \multirow[t]{2}{*}{ Female headed household } & $4.487 * *$ & 0.0581 \\
\hline & $(1.917)$ & $(1.776)$ \\
\hline \multirow[t]{2}{*}{ Dalit household } & 4.725 & $4.992 *$ \\
\hline & $(3.045)$ & $(2.640)$ \\
\hline \multirow[t]{2}{*}{ Janajati household } & -1.145 & $5.648 * * *$ \\
\hline & $(1.892)$ & $(1.747)$ \\
\hline \multirow[t]{2}{*}{ Number of household members } & 0.160 & 0.00782 \\
\hline & $(0.410)$ & $(0.390)$ \\
\hline \multirow[t]{2}{*}{ Area of land owned, in hectare } & $-17.60 * * *$ & -2.550 \\
\hline & $(3.125)$ & $(2.945)$ \\
\hline \multirow[t]{2}{*}{ Income from remittances } & -2.534 & $-3.612 * *$ \\
\hline & $(1.876)$ & $(1.716)$ \\
\hline $\mathrm{N}$ & 361 & 402 \\
\hline R-squared & 0.139 & 0.0883 \\
\hline
\end{tabular}

Source: BRACED Anukulan Baseline survey.

All regressions are conducted by authors. The coefficients are reported, along with the standard errors in parentheses.

The standard errors are clustered at the village development committee (VDC) level. ***, ** and * depict significance at 99\%, 95\% and 90\% respectively. 
Table T1. Women's decisions and the share of produce retained for household consumption in Tajikistan - OLS regression

\begin{tabular}{|c|c|c|c|c|c|c|c|}
\hline & Maize & Capsicum & Cucumber & Eggplant & Tomato & Onion & Potato \\
\hline Female decides share of harvest retained for hh-consumption & $-0.06(0.02)^{*}$ & $0.02(0.02)$ & $0.02(0.01)$ & 0.001 & $-0.01(0.01)$ & $0.01(0.01)$ & $0.01(0.01)$ \\
\hline Household with at least one male migrant & $-0.01(0.01)$ & $0.01(0.01)$ & $0.03(0.01)^{* * *}$ & $0.01(0.01)$ & $0.01(0.01)$ & $0.01(0.007)^{*}$ & $0.01(0.005)^{* *}$ \\
\hline Household earns income from wages & $0.02(0.02)$ & $0.01(0.01)$ & $0.02(0.01)$ & $0.01(0.01)$ & $0.02(0.01)^{* *}$ & $0.03(0.02)^{* *}$ & $0.01(0.01)$ \\
\hline Family size & $-0.01(0.01)$ & $-0.000(0.01)$ & $-0.01(0.01)$ & $-0.001(0.005)$ & $-0.01(0.004)$ & $-0.002(0.01)$ & $-0.002(0.005)$ \\
\hline Number of female members & $0.03(0.02)$ & $-0.02(0.01)$ & $0.01(0.01)$ & $0.01(0.01)$ & $0.01(0.01)^{* *}$ & $0.003(0.01)$ & $0.01(0.01)$ \\
\hline Age of the head of the household & $0.001(0.001)$ & $0.001(0.001)$ & $-0.001(0.001)$ & $-0.002(0.0003)$ & $-0.0002(0.0003)$ & $0.0001(0.0005)$ & $0.000(0.000)$ \\
\hline Household fetches drinking water from a public tap $\dagger$ & $0.05(0.02)^{* *}$ & $0.03(0.02)^{*}$ & $-0.01(0.02)$ & $-0.001(0.01)$ & $0.02(0.02)$ & $0.004(0.02)$ & $0.03(0.02)^{*}$ \\
\hline Presence of piped water in the house $\dagger$ & $0.05(0.02)^{* * *}$ & $0.04(0.02)^{* *}$ & $-0.01(0.02)$ & $-0.03(0.02)$ & $-0.002(0.01)$ & $0.02(0.02)$ & $-0.02(0.02)$ \\
\hline Gas or electric stove used for cooking & $0.03(0.02)$ & $-0.01(0.01)$ & $-0.01(0.02)$ & $-0.01(0.01)$ & $-0.001(0.01)$ & $0.02(0.02)$ & $0.01(0.01)$ \\
\hline Dwelling has wood flooring & $-0.003(0.02)$ & $-0.002(0.02)$ & $0.01(0001)$ & $0.01(0.01)$ & $0.003(0.01)$ & $0.02(0.02)$ & $0.01(0.01)$ \\
\hline Highest education attainment at least high school & $0.02(0.02)$ & $0.001(0.02)$ & $00001(0.02)$ & $0.002(0.01)$ & $-0.02(0.01)^{*}$ & $-0.01(0.02)$ & $0.001(0.01)$ \\
\hline At least one household member has vocational training & $-0.01(0.02)$ & $0.003(0.02)$ & $0.02(0.02)$ & $0.003(0.01)$ & $-0.01(0.01)$ & $-0.001(0.02)$ & $0.01(0.01)$ \\
\hline Female decides $*$ piped water in house & $-0.02(0.05)$ & $-0.02(0.03)$ & $-0.07(0.04)^{*}$ & $-0.02(0.04)$ & $-0.03(0.03)$ & $0.004(0.04)$ & $-0.03(0.04)$ \\
\hline Female decides $*$ household has male migrants & $0.01(0.04)$ & $0.01(0.02)$ & $-0.02(0.02)$ & $0.01(0.02)$ & $-0.001(0.01)$ & $-0.05(0.03)^{* *}$ & $-0.03(0.02)$ \\
\hline $\mathrm{N}$ & 523 & 863 & 784 & 651 & 1418 & 619 & 1213 \\
\hline Prob> F & 0.19 & 0.64 & 0.1318 & 0.8917 & 1915 & 0.2272 & 0.1095 \\
\hline R-squared & 0.04 & 0.02 & 0.03 & 0.01 & 0.01 & 0.02 & 0.120 \\
\hline
\end{tabular}

Source: Data collected by authors.

$\dagger$ these variables are dummies for source of domestic water: public tap or piped water in the house, with drawing water from canals as the default.

All regressions are conducted by authors. The coefficients are reported, along with the standard errors in parentheses.

The standard errors are clustered at the village level. ***, ** and * depict significance at 99\%, 95\% and 90\% respectively. 
Table B2. Women's decision and food shortage in Bangladesh

\begin{tabular}{|c|c|c|c|c|c|c|}
\hline & \multicolumn{4}{|c|}{ Tobit regressions } & \multirow{2}{*}{\multicolumn{2}{|c|}{$\begin{array}{l}\text { Logit regressions } \\
\begin{array}{l}\text { At least one month of } \\
\text { food shortage }\end{array}\end{array}$}} \\
\hline & $\begin{array}{r}\text { Number of } \\
\text { food } s\end{array}$ & $\begin{array}{l}\text { nonths with } \\
\text { ortage }\end{array}$ & $\begin{array}{r}\text { Number } \\
\text { with ac } \\
\text { sho }\end{array}$ & $\begin{array}{l}\text { ff months } \\
\text { ite food } \\
\text { tage }\end{array}$ & & \\
\hline agricultural produce & $\begin{array}{l}-0.726^{*} \\
(0.431)\end{array}$ & & $\begin{array}{l}-2.461 \\
(1.855)\end{array}$ & & $\begin{array}{l}-0.0405 \\
(0.0539)\end{array}$ & \\
\hline $\begin{array}{l}\text { Female decides how to use income } \\
\text { from crop sales }\end{array}$ & & $\begin{array}{c}-1.404 * * * \\
(0.417)\end{array}$ & & $\begin{array}{c}-5.375^{* *} \\
(2.308)\end{array}$ & & $\begin{array}{l}-0.176^{* * * *} \\
(0.0482)\end{array}$ \\
\hline Wealth index & $\begin{array}{c}-0.408^{* * * *} \\
(0.100)\end{array}$ & $\begin{array}{c}-0.419 * * * \\
(0.0998)\end{array}$ & $\begin{array}{l}-0.457 \\
(0.382)\end{array}$ & $\begin{array}{l}-0.304 \\
(0.371)\end{array}$ & $\begin{array}{c}-0.0644 * * * \\
(0.0130)\end{array}$ & $\begin{array}{c}-0.0641 * * * \\
(0.0128)\end{array}$ \\
\hline Area of land owned, in hectare & $\begin{array}{c}-1.804 * * * \\
(0.324)\end{array}$ & $\begin{array}{c}-1.482 * * * \\
(0.298)\end{array}$ & $\begin{array}{l}-0.757 \\
(0.946)\end{array}$ & $\begin{array}{l}-0.686 \\
(0.913)\end{array}$ & $\begin{array}{c}-0.214 * * * \\
(0.0460)\end{array}$ & $\begin{array}{c}-0.175^{* * *} \\
(0.0416)\end{array}$ \\
\hline Hindu & $\begin{array}{l}-0.435 \\
(0.380)\end{array}$ & $\begin{array}{l}-0.450 \\
(0.378)\end{array}$ & $\begin{array}{l}2.719 * \\
(1.438)\end{array}$ & $\begin{array}{l}2.344 * \\
(1.392)\end{array}$ & $\begin{array}{l}-0.0572 \\
(0.0479)\end{array}$ & $\begin{array}{l}-0.0553 \\
(0.0473)\end{array}$ \\
\hline Female headed household & $\begin{array}{l}1.665^{* * *} \\
(0.540)\end{array}$ & $\begin{array}{c}1.675^{* * *} \\
(0.546)\end{array}$ & $\begin{array}{l}-2.242 \\
(2.246)\end{array}$ & $\begin{array}{l}-1.188 \\
(2.063)\end{array}$ & $\begin{array}{l}0.178^{* * *} \\
(0.0664)\end{array}$ & $\begin{array}{l}0.176^{* * *} \\
(0.0664)\end{array}$ \\
\hline Age of the head of the household & $\begin{array}{l}-0.00441 \\
(0.0135)\end{array}$ & $\begin{array}{l}-0.00318 \\
(0.0132)\end{array}$ & $\begin{array}{l}-0.0346 \\
(0.0519)\end{array}$ & $\begin{array}{l}-0.0291 \\
(0.0499)\end{array}$ & $\begin{array}{l}-0.000305 \\
(0.00173)\end{array}$ & $\begin{array}{l}-0.000186 \\
(0.00170)\end{array}$ \\
\hline $\mathrm{N}$ & 583 & 593 & 583 & 593 & 583 & 593 \\
\hline Pseudo R-squared & 0.0398 & 0.0392 & 0.0249 & 0.0351 & 0.1063 & 0,1082 \\
\hline
\end{tabular}

Source: Data collected by authors.

All regressions are conducted by authors. The coefficients are reported for tobit regression and marginal effects $(d y / d x)$ are reported for logit regressions, along with the standard errors in parentheses.

The standard errors are clustered at the village level. $* * * * *$ and $*$ depict significance at $99 \%, 95 \%$ and $90 \%$ respectively. 
Table N2. Women's empowerment and the yields of cereals in Nepal-OLS regression

\begin{tabular}{|c|c|c|}
\hline & $\begin{array}{c}\text { Rice } \\
\text { productivity }\end{array}$ & $\begin{array}{c}\text { Wheat } \\
\text { productivity }\end{array}$ \\
\hline \multirow[t]{2}{*}{ Input in productive decisions } & 161.3 & -186.0 \\
\hline & $(177.0)$ & $(144.4)$ \\
\hline \multirow[t]{2}{*}{ Control over the income } & -160.8 & $284.9 * *$ \\
\hline & $(150.6)$ & $(127.8)$ \\
\hline \multirow[t]{2}{*}{ Ownership of assets } & $669.6^{*}$ & 112.6 \\
\hline & $(378.3)$ & $(348.8)$ \\
\hline \multirow[t]{2}{*}{ Access to and decisions about credit } & 101.4 & $-481.0 * * *$ \\
\hline & (133.9) & $(108.2)$ \\
\hline \multirow[t]{2}{*}{ Group membership } & 61.99 & -1.803 \\
\hline & $(121.4)$ & $(97.86)$ \\
\hline \multirow[t]{2}{*}{ Workload } & 133.2 & 146.5 \\
\hline & $(142.3)$ & $(118.8)$ \\
\hline \multirow[t]{2}{*}{ Age head of the household } & -2.230 & $-8.494 * *$ \\
\hline & $(5.163)$ & $(4.172)$ \\
\hline \multirow[t]{2}{*}{ Female headed household } & -2.956 & -158.8 \\
\hline & $(136.5)$ & $(111.0)$ \\
\hline \multirow[t]{2}{*}{ Dalit household } & -195.8 & -155.5 \\
\hline & $(180.6)$ & $(150.9)$ \\
\hline \multirow[t]{2}{*}{ Janajati household } & $307.0 * *$ & $351.4 * * *$ \\
\hline & $(135.0)$ & $(111.3)$ \\
\hline \multirow[t]{2}{*}{ Number of household members } & 33.44 & 20.78 \\
\hline & $(30.05)$ & $(24.76)$ \\
\hline \multirow[t]{2}{*}{ Area of land owned, in hectare } & -145.8 & -31.90 \\
\hline & $(225.9)$ & $(176.6)$ \\
\hline \multirow[t]{2}{*}{ Income from remittances } & 177.4 & $295.9 * * *$ \\
\hline & $(128.9)$ & $(106.8)$ \\
\hline $\mathrm{N}$ & 422 & 397 \\
\hline R-squared & 0.049 & 0.121 \\
\hline
\end{tabular}

Source: BRACED Anukulan baseline survey.

All regressions are conducted by authors. The coefficients are reported, along with the standard errors in parentheses.

The standard errors are clustered at the VDC level. ***, ** and * depict significance at 99\%, 95\% and 90\% respectively. 
Table T2. Women's decisions and the adoption of a coping strategy in Tajikistan-logit regression

\begin{tabular}{|c|c|c|c|c|c|c|c|}
\hline & Eat cheap food & $\begin{array}{c}\text { Reduce } \\
\text { quantity in } \\
\text { each meal }\end{array}$ & $\begin{array}{c}\text { Spend day } \\
\text { without eating }\end{array}$ & $\begin{array}{l}\text { Borrow money } \\
\text { from friends }\end{array}$ & $\begin{array}{l}\text { Purchase food } \\
\text { on credit }\end{array}$ & $\begin{array}{l}\text { Eat stored } \\
\text { seeds }\end{array}$ & $\begin{array}{l}\text { Sell items } \\
\text { for money }\end{array}$ \\
\hline \multirow[t]{2}{*}{ Female decides share of harvest retained for hh consumption } & $0.158 * * *$ & $0.123 * * *$ & 0.0401 & -0.00869 & $0.0830^{* *}$ & 0.0367 & -0.0158 \\
\hline & -0.0367 & -0.0368 & -0.0244 & -0.0344 & -0.0361 & -0.0363 & -0.0358 \\
\hline \multirow{2}{*}{ Household with at least one male migrant } & 0.0219 & 0.0159 & -0.0259 & -0.0209 & 0.0035 & -0.037 & $-0.0425 *$ \\
\hline & -0.0228 & -0.0234 & -0.0184 & -0.0223 & -0.0226 & -0.0231 & -0.0228 \\
\hline \multirow{2}{*}{ Household earns income from wages } & -0.00204 & $-0.0643 * *$ & -0.0163 & -0.0284 & 0.0172 & -0.0256 & 0.0134 \\
\hline & -0.0282 & -0.0285 & -0.02 & -0.0266 & -0.0277 & -0.0281 & -0.0278 \\
\hline \multirow[t]{2}{*}{ Family size } & $-0,00488$ & $-0,00267$ & $-0,00593$ & $-0,0168$ & 0,00658 & $0.0265^{* * *}$ & $0.0417 * * *$ \\
\hline & $-0,0131$ & $-0,0134$ & $-0,00963$ & $-0,0126$ & $-0,013$ & $-0,0131$ & $-0,0129$ \\
\hline \multirow[t]{2}{*}{ Number of female members } & $-0,00167$ & $-0,00641$ & 0,00102 & 0,03 & 0,0232 & $-0.0415 *$ & $-0,0333$ \\
\hline & $-0,023$ & $-0,0235$ & $-0,0168$ & $-0,022$ & $-0,023$ & $-0,0231$ & $-0,0227$ \\
\hline \multirow[t]{2}{*}{ Age of the head of the household } & 0,00109 & 0,00128 & 0,00053 & $-0,000842$ & 0,000407 & $0.00202 *$ & 0,000103 \\
\hline & $-0,00106$ & $-0,00108$ & $-0,000747$ & $-0,00101$ & $-0,00104$ & $-0,00106$ & $-0,00105$ \\
\hline \multirow[t]{2}{*}{ Household fetches drinking water from a public tap $\dagger$} & $-0.0733 * *$ & $-0.0961 * * *$ & $-0,0267$ & $-0,0386$ & $0.0624 *$ & $-0.0789 * *$ & $-0,00422$ \\
\hline & $-0,0358$ & $-0,0353$ & $-0,024$ & $-0,0327$ & $-0,0343$ & $-0,0347$ & $-0,035$ \\
\hline \multirow[t]{2}{*}{ Presence of piped water in the house $\dagger$} & $-0.284 * * *$ & $-0.342 * * *$ & $-0.0885^{* *}$ & $-0.214 * * *$ & $-0.170 * * *$ & $-0.196^{* * *}$ & $-0.150^{* * * *}$ \\
\hline & $-0,0636$ & $-0,0564$ & $-0,0403$ & $-0,0506$ & $-0,0659$ & $-0,0583$ & $-0,0575$ \\
\hline \multirow[t]{2}{*}{ Gas or electric stove used for cooking } & $-0.0981 * * *$ & $-0.0804 * * *$ & $-0.0392 * *$ & $-0.0558^{* *}$ & -0.0142 & $-0.0840^{* * *}$ & $-0.105^{* * *}$ \\
\hline & -0.0278 & -0.0283 & -0.0198 & -0.0263 & -0.0276 & -0.0276 & -0.0271 \\
\hline \multirow[t]{2}{*}{ Dwelling has wood flooring } & -0.0449 & -0.039 & $-0.0570^{* * *}$ & -0.0349 & $-0.114 * * *$ & 0.0205 & -0.0226 \\
\hline & -0.0285 & -0.0289 & -0.0196 & -0.0268 & -0.0279 & -0.0284 & -0.028 \\
\hline \multirow[t]{2}{*}{ Highest education attainment at least high school } & $-0.159^{* * * *}$ & $-0.0877 * *$ & $-0.0718^{* * *}$ & -0.0257 & -0.0308 & -0.00898 & -0.0102 \\
\hline & -0.0384 & -0.0386 & -0.0232 & -0.0361 & -0.0378 & -0.0381 & -0.0377 \\
\hline \multirow[t]{2}{*}{ At least one household member has vocational training } & -0.0135 & -0.0133 & -0.033 & 0.0106 & 0.0166 & -0.0337 & -0.000927 \\
\hline & -0.0339 & -0.0344 & -0.0223 & -0.0322 & -0.0333 & -0.0335 & -0.0333 \\
\hline \multirow[t]{2}{*}{ Female decides* piped water in house } & 0.123 & 0.139 & 0.0625 & $0.196^{*}$ & $0.159 * *$ & 0.0594 & -0.023 \\
\hline & -0.0753 & -0.0904 & -0.0994 & -0.105 & -0.0682 & -0.0915 & -0.0914 \\
\hline Female decides * household has male migrants & $-0.140 * * *$ & $-0.0911 *$ & -0.0249 & 0.0343 & -0.0247 & 0.00276 & 0.00338 \\
\hline
\end{tabular}




\begin{tabular}{|c|c|c|c|c|c|c|c|}
\hline & -0.0484 & -0.0479 & -0.0327 & -0.0458 & -0.0471 & -0.0473 & -0.047 \\
\hline $\mathrm{N}$ & 1441 & 1441 & 1441 & 1441 & 1441 & 1441 & 1441 \\
\hline Pseudo R-squared & 0.0478 & 0.0464 & 0.0351 & 0.018 & 0.0304 & 0.0239 & 0.0309 \\
\hline
\end{tabular}

Source: Data collected by authors.

$\dagger$ these variables are dummies for source of domestic water: public tap or piped water in the house, with drawing water from canals as the default.

All regressions are conducted by authors. The marginal effects $(d y / d x)$ are reported, along with the standard errors in parentheses.

The standard errors are clustered at the village level. ***, ** and $*$ depict significance at $99 \%, 95 \%$ and $90 \%$ respectively 
Table B3. Women's decision and coping strategies in Bangladesh

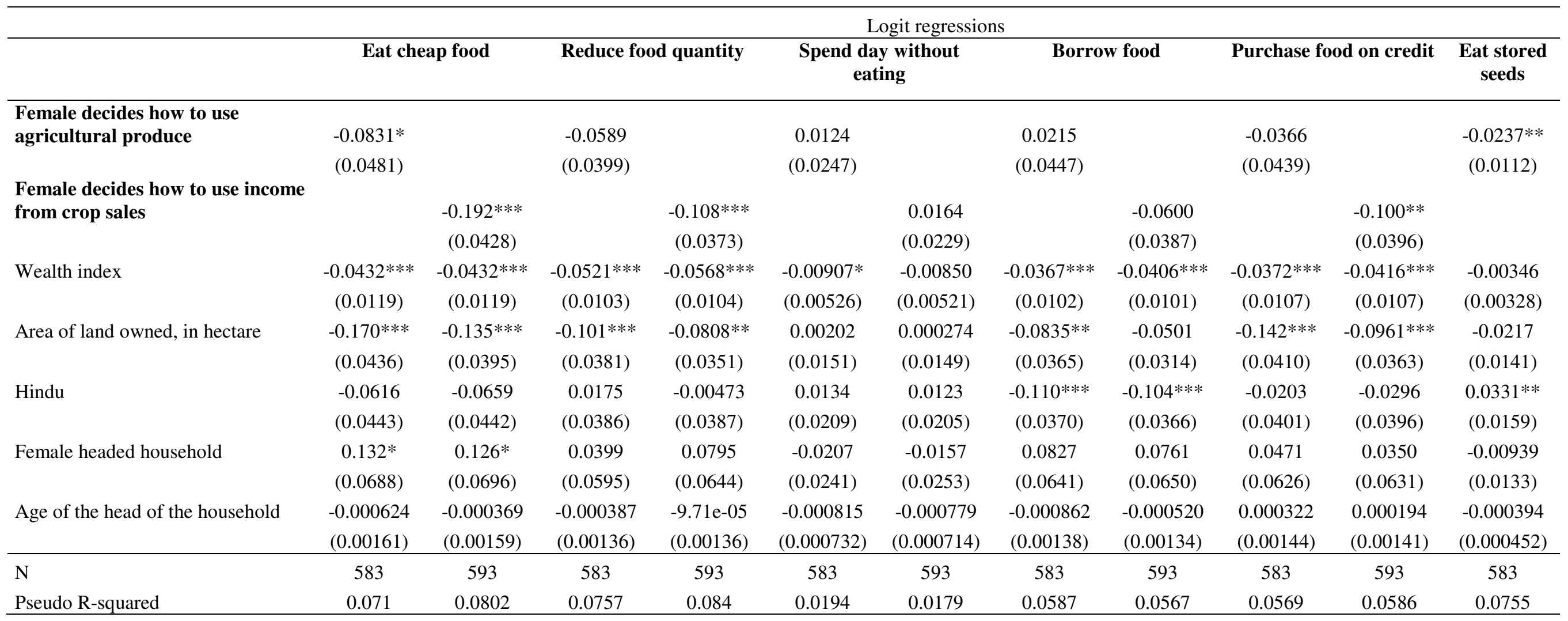

Source: Data collected by authors.

All regressions are conducted by authors. The marginal effects $(d y / d x)$ are reported, along with the standard errors in parentheses.

The standard errors are clustered at the village level. ***, ** and * depict significance at 99\%, 95\% and 90\% respectively. 
Table N3. Women's empowerment and the likelihood of malnutrition for under 2 children - logit regression

\begin{tabular}{|c|c|c|c|}
\hline & Stunting & Wasting & Underweight \\
\hline \multirow[t]{2}{*}{ Input in productive decisions } & -0.0338 & -0.0122 & -0.0264 \\
\hline & $(0.0848)$ & $(0.0591)$ & $(0.0715)$ \\
\hline \multirow[t]{2}{*}{ Control over the income } & 0.0845 & -0.0485 & 0.0323 \\
\hline & $(0.0791)$ & $(0.0615)$ & $(0.0605)$ \\
\hline \multirow[t]{2}{*}{ Ownership of assets } & 0.0689 & & -0.102 \\
\hline & $(0.300)$ & & $(0.281)$ \\
\hline \multirow[t]{2}{*}{ Access to and decisions about credit } & $-0.135^{* *}$ & -0.0406 & $-0.121 * *$ \\
\hline & $(0.0678)$ & $(0.0464)$ & $(0.0527)$ \\
\hline \multirow[t]{2}{*}{ Group membership } & 0.0520 & -0.0185 & -0.0531 \\
\hline & $(0.0644)$ & $(0.0447)$ & $(0.0525)$ \\
\hline \multirow[t]{2}{*}{ Workload } & 0.0376 & 0.0283 & -0.0500 \\
\hline & $(0.0788)$ & $(0.0515)$ & $(0.0676)$ \\
\hline \multirow[t]{2}{*}{ Age head of the household } & 0.00110 & $-0.00482 * *$ & -0.00293 \\
\hline & $(0.00277)$ & $(0.00196)$ & $(0.00221)$ \\
\hline \multirow[t]{2}{*}{ Female headed household } & -0.0389 & -0.0409 & -0.0168 \\
\hline & $(0.0744)$ & $(0.0495)$ & $(0.0590)$ \\
\hline \multirow[t]{2}{*}{ Dalit household } & $-0.186^{* *}$ & -0.0655 & -0.0678 \\
\hline & $(0.0822)$ & $(0.0499)$ & $(0.0612)$ \\
\hline \multirow[t]{2}{*}{ Janajati household } & -0.0986 & -0.0493 & -0.0888 \\
\hline & $(0.0726)$ & $(0.0478)$ & $(0.0568)$ \\
\hline \multirow[t]{2}{*}{ Number of household members } & 0.00930 & $0.0211 * *$ & 0.0154 \\
\hline & $(0.0162)$ & $(0.0107)$ & $(0.0128)$ \\
\hline \multirow[t]{2}{*}{ Area of land owned, in hectare } & -0.0691 & -0.0335 & 0.000633 \\
\hline & $(0.114)$ & $(0.0786)$ & $(0.0858)$ \\
\hline \multirow[t]{2}{*}{ Income from remittances } & -0.0509 & $-0.119 * * *$ & -0.0270 \\
\hline & $(0.0678)$ & $(0.0422)$ & $(0.0530)$ \\
\hline $\mathrm{N}$ & 265 & 264 & 267 \\
\hline Pseudo R-squared & 0.0387 & 0.0687 & 0.0441 \\
\hline
\end{tabular}

Source: BRACED Anukulan baseline survey.

All regressions are conducted by authors. The marginal effects (dy/dx) are reported, along with the standard errors in parentheses.

The standard errors are clustered at the VDC level. ***,** and * depict significance at $99 \%, 95 \%$ and $90 \%$ respectively. 